\title{
APPRAISAL OF THE IMPLEMENTATION OF LAND-USE REGULATIONS ON COMMERCIAL PROPERTY DEVELOPMENT IN ILORIN, NIGERIA
}

\author{
AbdulAkeem Olasunkanmi Otunola \\ Department of Estate Management \& Valuation, \\ Federal Polytechnic Offa, Kwara State, Nigeria
}

\author{
Michael Adedayo Adebayo \\ Department of Estate Management \\ Federal University of Technology Akure, \\ Ondo State, Nigeria
}

\begin{abstract}
The implementation of land use regulations on commercial property development is extremely important because of benefits abound in it for the society. Ilorin the capital of Kwara state, Nigeria is experiencing influx of many residents which gave rise to series of urban challenges. This paper appraised the implementation of land use regulations on commercial property development in Ilorin, Nigeria. The study adopted survey research design and census method was adopted for the commercial properties and Estate Surveying and Valuation firms in the study area. Questionnaires were distributed to 26 practicing Estate firms in Ilorin Kwara State, 110 and 39 selected landlords / occupiers of commercial properties in Gambari-Ipata-Emir's road and Government Reserved Area in Ilorin, Nigeria. Out of which 24 questionnaires $(92 \%)$ and $110(100 \%), 36(92 \%)$ were returned and found useful for the study. Data collected were analysed using descriptive statistics of cross tabulation and inferential statistics of Independent Sample $t$ - Test and test of hypothesis. The research revealed that the p-values were all greater than 0.01 which led to the acceptance of null hypothesis that the level of implementation of land use regulations on commercial property development does not vary in the study area. The study conclude that there were hindrances to effective implementations of land use regulations on commercial property development across the study areas, and if not corrected will continue to affect the welfare of the citizens, ease of commercial activities, will lead to falling in commercial property's rental value, falling in urban aesthetic value, and an increase in externalities. The study recommended proper government intervention in providing better resources to improve the level of monitoring and enforcement of land use regulations on commercial property development.
\end{abstract}

Keywords: Commercial property, development, land use regulations, urban - center, Nigeria.

\section{INTRODUCTION}

\subsection{Background to the Study}

Land use is generally regulated throughout the world and its impact has been very significant on the environment, particularly on the landed properties. Land use connotes development and its patterns which arise as a result of human activities (Braissoulis, 1999; Oduwaiye, Alade \& Adekunle, 2011). As urban centres continue to grow, demand for various land uses also increases correspondingly, land use regulations tend to influence land use decisions within larger cities (Fischel, 2004). Land use choices have effects on land prices, neighborhood composition, housing quality and government services, etc (Jaeger, 2006).

Property development obviously shapes future urban scene as it allows public planners to provide residents with sense of cohesion and security. This further contribute to job creation and a more prosperous and viable economy (Power, 2004). It is pertinent to note that property development process play vital role in creating new space and growth of cities (Guy and Henneberry, 2005; Hang Wang, 2002). However, to sacrifice environmental quality in exchange for property developments is inimical to welfare of the populace. Commercial property accommodates different business activities such as retail premises which offer potential work place for citizens and serves as revenue source to the government, social interactive place and business catalyst for an area. It has economic, environmental, political, social and cultural influences (Toivonen and Viitanen, 2016).

It can be inferred from its influences that, commercial property development brings rapid changes to land uses. It is however curtailed by the law or reform policy, modifying the quality of right/tenure, location of activities, type of uses, density of use, occupancy ratio, rent control, price paid among others. Land use regulations became increasingly important in any nation in order to overcome the problems of haphazard, uncontrolled development, deteriorating environmental quality, loss of prime agricultural land, destruction of 


\section{International Journal of Engineering Applied Sciences and Technology, 2021 \\ Vol. 6, Issue 5, ISSN No. 2455-2143, Pages 88-99 \\ Published Online September 2021 in IJEAST (http://www.ijeast.com)}

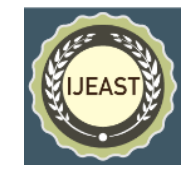

important wetlands, loss of fish and wildlife habitat and loss of revenue to the government.

Land use regulations includes a wide variety of rule governing the physical location of economic activities within jurisdictions; regulations governing the design, height, or capital intensity of commercial and industrial property; and rules regarding the minimum lot sizes. It includes regulations such as zoning, height and density restriction; as well as, growth moratoria that influence commercial property development (Evans, 2004).

The importance of land use regulations on property development cannot be over emphasized as it helps to correct market failure and externalities (Robert-Nicoud \& Hilber, 2013; Turner, Haughwout, and Vander, 2014). Glaeser and Ward (2009), found that there is correlation between types of regulations and the level of new constructions. Land use regulations has amenity impacts, the amenity impacts include to protect environmental quality, open space, ground water availability and its quality, or to reduce noise, congestion, or pollution, preservation of agricultural lands and lands with historical significance (Spark, 2009; Jaeger, 2006).

It is worthy of note that, land use regulations are ancient phenomenon and are often quite restrictive in highly metro area in United State but quite relaxed in many other places in U. S and Europe. In other words, land use regulations' scope varies tremendously in implementation and across space in developed countries (Glaeser, Gyourko \& Saks, 2005; Cheshire \& Hilber, 2008; Hilber \& Robert-Nicoud, 2011).

Fischel (2004) maintained that strict implementation of land use regulations reflects the wishes of majority and helps to increase the value of properties to the owners by protecting these properties. However, the study of Gyouko, Saiz and Summers (2008), shows that land use regulations has negative effect on urban development. In the opinion of Bramley (2013), there exists the impact of land use regulation on property development. In addition, Glaeser (2017), submitted that land use regulation does not have negative impact on national economic success of America as it supported the development of more housing.

Meanwhile, Government regulation of land uses raises important questions as for any proposed development by developers it must meet up with the laid down regulations guiding the developments in a particular community to avoid negative impacts. Such regulations that tend to limit negative impacts include building restrictions, environmental zoning, etc. (Jaeger, 2006). According to Oyesiku (1998), while the general objective of land use regulations encompasses promotion of public health, accessibility, convenience, harmonious land use, safety, moral and general welfare, it is the duty of government to regulate land uses. The implementation of land use regulations can be view from three perspectives; it may allow land owners or developers to avoid compliance, granting exemptions and then enacting or implementation of strict regulations (Spark, 2009). The implementation of land use regulations are expected to promote public purposes, correct externalities and must conform to the policies and guide lines, (Turner, Haughwout, and Vander, 2014).

In order to ensure adequate provision of various land uses and meet the needs of users of urban facilities and services, various land use regulations are established by the government. Be it as it may, various regulations in Nigeria such as Land Use Act of 1978 now CAP 202 LFN, 1990, Police Power, and Power of eminent domain among others are referred to as land use regulations. Land use regulations will be of great benefits to all and sundry when they are properly implemented. It will enhance the supply of good property development. It is very important to appraise the implementation of land use regulations on commercial property development in Ilorin Kwara State, Nigeria.

\subsection{Research Questions}

As a result of problem statement, the following research questions are put forward:

What are the land use regulations? What is the level of implementation of land use regulations on commercial property development in the study area?

The research provides answers to the above questions by collecting and analyzing the required data using appropriate research techniques.

\subsection{Aim and Objectives}

The aim of this study is to appraise the implementation of land use regulations on commercial property development in Ilorin, Nigeria with a view to enhancing the supply of sustainable commercial properties to the market.

\subsection{Research Hypothesis}

Based on the aim and objectives of this research, the hypothesis postulated is:

\section{Hypothesis \\ $\mathrm{H}_{0}$ : Level of implementation of land use regulations for commercial property development does not vary in the study areas of Ilorin. \\ $\mathrm{H}_{1}$ : Level of implementation of land use regulations for commercial property development varies in the study areas of Ilorin.}

\subsection{Significance of the Study}

Studies on the implementation of land use regulations on commercial property development are very few. It is very imperative for a study to be carried out to appraise the implementation of land use regulations on commercial property development. This research therefore, appraised the implementation of land use regulations on commercial property development in Ilorin, (from Amilegbe junction through Gambari-Ipata-Emir's road to Ita-ajia area and 


\section{International Journal of Engineering Applied Sciences and Technology, 2021 \\ Vol. 6, Issue 5, ISSN No. 2455-2143, Pages 88-99 \\ Published Online September 2021 in IJEAST (http://www.ijeast.com)}

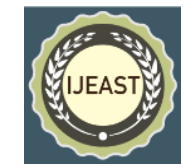

Central Bank of Nigeria (CBN) office to flower-garden junction of Offa road, Government Reserved Area), Kwara State, Nigeria.

Different studies have been carried out on the implementation of land use regulations on property development in many countries of the world. Existing literatures have examined the planning regulation and implementation mechanism, stringency and implementation of land use regulations on property development and barrier to successful implementation of land use regulations on property development and has received more attention and publicity while the study of the implementation of land use regulations on commercial property development are not so common especially in Nigeria. Gocmen (2013), examined barriers to successful implementation of conservation sub division design with critical analysis of land use regulation and subdivision permitting process in United State of America. The author adopted document review of zoning and interview of developers. The study found out that the successful implementation of land use regulation was hindered by zoning ordinance and the permitting process.

Brueckner (2017), examined the stringency of land use regulation in China. The study employed national sample and the results revealed that there was variation in implementation of land use regulation across Chinese cities and with site characteristics. Abiodun, Olaitan, and Abimbola (2018), also assessed the planning regulations and implementation mechanism in post - colonial Lagos. The authors adopted literature survey and survey approach in order to establish the mechanism for land use regulations' implementation and challenges existing in the case study. The study found out that there was weak implementation of land use regulations, lack of political will for proper implementation of land use regulations, conflicts between town planners, political elites and the urban poor which resulted to incompatible land use developments in Lagos state.

Wang and Zhang (2014), assessed the land use regulations and implementation in urban China. The study utilized data set of land parcels in similar manner with residential development projects comprising 30 major cities in Chinese. The result revealed that market incentives drove developers to add more floors in lucrative locations to capture the value of land. Furthermore, lucrative locations induce violation and that corruption boosts violation of land use regulations.

Though, these studies focused on implementation of land use regulations on landed properties, but there is existence of a research gap especially in Nigeria.

Previous studies that are related to this research include the study of Hanushek and Quigley (2012) on Commercial Land Use, Land Use Regulation and Local Government Finance in America. The study investigates zoning as a popular form of land use regulations. The authors employed
Case-Gordon (C-G) model and Rosen-Shragowitz (R-S) model and posit that the rent and value of commercial property and residential property increases as a result of restrictions. The study concluded that without empirical studies it is very difficult to understand policies toward commercial properties. The key variables to be explained in the empirical analysis should be selected from the regulation indicators. The study of Goyita and Pasquini (2010; 2015) created the thematic indicators for land use regulation implementation which includes Land Use Plan Regulation existence indicator, Project Approval Indicator, Access to Land Regulation Indicator, Approval Cost Indicator, Public Service (infrastructure) Provision Indicator, Building Restriction Indicator, among others.

However, there are few studies found on the implementation of land use regulations on commercial property development, as those studies found in developed countries were carried out on other landed properties other than the one currently being examined. As such, there is paucity of study on implementation of land use regulations on commercial property development especially in Nigeria. Thus, this study attempts to fill the gap.

Land use regulations cut across urban and town planning as well as estate management and valuation. Thus, urban and town planner focuses on urban land use planning, while estate surveyors and valuer focuses on land use, resources development, urban development and management, etc. Zoning and building regulations confer benefits to real estate properties (to promote concentrated of economic activities, regulates higher-density, mixed-use development in designated areas among others). The study of zoning and building regulations by estate management and valuation appraised the implementation of land use regulation on commercial property development in a way that promotes urban aesthetic value, correct externalities, promotes welfare of the citizen, ease of commercial activities and enhance the supply of good commercial properties to the market.

Therefore, in this research a study was carried out to appraise the implementation of land use regulations on commercial property development. This study became very necessary considering the fact that the study of implementation of land use regulation on commercial property development which is currently lacking within the domain of Estate Surveyors and Valuers in the study area was explored. The study will encourages the populace to embrace thoughtful planning and assist in providing cleaner environment that is free from traffic grid lock, noise pollution, haphazard development, parking lots problem as well ensuring adequate open space and parking lots. These will enhance adequate management of commercial property for maximum returns for the investors. This study helps to reduce inconvenience for the urban populace as it helps to improve movement and accessibility of vehicular and pedestrians. The study will contributes to economic development of the state by assisting the government and it 


\section{International Journal of Engineering Applied Sciences and Technology, 2021 \\ Vol. 6, Issue 5, ISSN No. 2455-2143, Pages 88-99 \\ Published Online September 2021 in IJEAST (http://www.ijeast.com)}

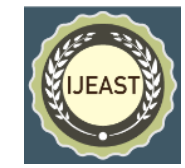

agencies in land matters and land policy to take steps in improving efficiency of land use practices in Ilorin urban.

The study will contributes to the development of an ideal metropolis of Ilorin as a state capital with ample opportunities for commercial property investment. It will contributes to the judicious use of land, location of activities, controlling density of use, occupancy ratio, rent control; price paid and enhances tax policy instruments. Finally, it will provide basis for further research in this field subsequently, as it provides new explanation to the topic. Built environment professionals, real estate investors, scholars and policy makers would all find this study useful.

\subsection{Scope of the study}

The study appraised the implementation of land use regulations on commercial property development in Ilorin. It focuses on the implementation of land use regulations on commercial property development in Amilegbe junction through Gambari-Ipata-Emir's road to Ita-ajia area and Central Bank of Nigeria (CBN) office to flower-garden junction of Offa road, Government Reserved Area (G.R.A) Ilorin, Kwara State.

The geographical scope of the study has been confined to Amilegbe - Gambari - Ipata - Emirs road- ita ajia and C.B.N road - Offa road - to flower garden junction, G.R.A, Ilorin Kwara state. While the contents scope is on the welfare impacts resulting from the zoning and building regulations.

It is to be noted that, the most widely studied by most urban economist in the analysis of land use regulations is zoning. This study focuses on zoning and building regulation through survey of landlord/tenants of selected commercial properties, regulators (Officials of Kwara State Physical Planning Authority) and Estate Surveyors and Valuers'firm to analyze the data.

\subsection{The Study Area}

Ilorin the study area is a city in North-Central Nigeria and is the largest city and capital of kwara State. Ilorin is located on latitude $8^{0} 30^{1} \mathrm{~N}$ and longitude $4{ }^{0} 35^{1} \mathrm{E}$. It lies in the transitional zone of the middle belt and serves as a gateway city between the North and South-West part of the country. The city, which lies along Kaduna high way. It is 306 kilometers from Lagos, 600 kilometers from Kaduna and about 500 kilometers from Abuja. Ilorin has a tropical wet and dry climate and a mean rainfall of about $1318 \mathrm{~mm}$, which begins in April and end in November.

The 2006 population census figure revealed that there are 2,371,089 people in Kwara State with annual growing rate of $6.2 \%$ (NPC, 1991,2006: Odeniyi, 2007). The study area has three (3) local governments that comprises of Ilorin East, Ilorin west and Ilorin South, but the two (2) main local governments Ilorin west and Ilorin South has direct bearing to city center which forms the focus of this study.
The continuous physical, economic and population growth of Ilorin has been accompanied by the occupancy of the existing space by different types of land use, mainly residential and commercial. The three major areas of commercial activities concentration are Emir's market, Taiwo/Unity road axis. Most of properties that were hitherto designed for residential purposes in these areas have been converted to commercial properties.

The choice of Ilorin as a case study was based on the fact that the pattern of an urban centre continues to increase both in demand and supply for commercial property in Ilorin North Central Nigeria as commercial properties are prominent in both core city centre (from Amilegbe junction through Gambari-Ipata-Emir's road to Ita-ajia area) and Central Bank of Nigeria $(\mathrm{CBN})$ office to flower-garden junction of Offa road, Government Reserved Area (G.R.A) Ilorin, Kwara State. Thus, this study serves as spring board for more understanding of the implementation of land use regulations on commercial property development in Kwara State.

\section{LITERATURE REVIEW}

\subsection{Land Use Regulations}

Land use regulations are tools employed by the government to provide residents with sense of cohesion and security and to contribute to job creation and a more prosperous and viable economy in most of developed and developing countries of the world (Evans, 2004).

Hanushek and Qugley (2012) submitted that land use regulations include a wide variety of rule governing the physical location of economic activities within jurisdictions; regulations governing the design, height, or capital intensity of commercial and industrial property use; rules regarding the minimum lot sizes for property development and rules delineating developer responsibilities for infrastructure provided in newly subdivided areas. Land use regulations also include housing codes, regulations for subdivisions, zoning ordinances, and building codes, etc. Land use regulation, also sometimes referred to as urban development regulations or controls, are rules which indicate how land in particular areas can be used and developed (Goodfellow, 2014a). Land use regulations serve the purpose of restricting development in order to give effect to urban plans. Land use regulations further includes; land use act of 1978, zoning, building permit, fiscal measure (property taxation), historic preservation law, curve cut permit, tree cutting law, police power measures, eminent domain (taking), town planning regulations (sanitary ordinance, planning permission, sub-division regulations, building regulations, etc.), housing and property development regulations, traffic and transportation regulations, urban renewal regulations, pollution and environmental regulation, recreational regulations, rent and land use charge regulations (rent control edict, land charge). Other types of land use regulations includes; building codes or building regulation, 


\section{International Journal of Engineering Applied Sciences and Technology, 2021 \\ Vol. 6, Issue 5, ISSN No. 2455-2143, Pages 88-99 \\ Published Online September 2021 in IJEAST (http://www.ijeast.com)}

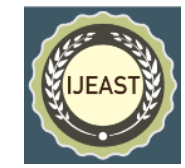

Infrastructure standards, minimum plot size, subdivision regulation, Floor Area Ratios and Limits (FAR), etc.

\subsection{Level of Implementation of Land Use Regulations for Commercial Property Development.}

Sridhar (2010), examined the impact of land use regulations in India in terms of strong implementation of land use regulations using econometric techniques. The study found that population suburbanises in response to a relaxation of floor area ratio norms in the suburbs.

Boama, Nelson and Gyimah (2012), examined the implementation of land use regulations and its impact on land value in Ghana. The author reviewed literatures and collated empirical data from land developers so as to find out whether developers are complying with the system of land use regulations in the municipality and to also document the level of implementation of these regulations. The study found that development controls are largely not enforced in Wa municipality, as a result of building codes not consistent with the socio-economic state of the municipality's residents and led to haphazard development and reduction in land value. The study can be subjected to bias in its method of data collection from developers who may compromise, because information on compliance and implementation of the land use regulations can better be obtained from regulators and residents who are knowledgeable in land use regulations and were independent.

The present study appraised the implementation of land use regulations on commercial property development and adoption of descriptive method, survey of landlord/tenants of selected commercial properties, regulators (Officials of Kwara State Physical Planning Authority) and Estate Surveyors and Valuers'firm helps to achieve the aim of the study.

Wang and Zhang (2014), assessed the land use regulations and implementation in urban China. The study utilized data set of land parcels in similar manner with residential development projects comprising 30 major cities in Chinese. The result revealed that market incentives drove developers to add more floors in lucrative locations to capture the value of land. Furthermore, lucrative locations induce violation and that corruption boosts violation of land use regulations. The study helps to establish basis for assessing the land use regulations implementation across many urban areas.

Several empirical studies have showed that implementation of land use regulations varies across metropolitan areas and the stringency of regulations, for instance, Goytia and Pasquini (2013). Goytia and Pasquini (2013) studied the impact of land use regulations on land development in Argentina. The author made use of quantitative data in relation to degree of strict implementation and flexibility of selected regulation indicators gathered from survey of the municipalities and employed descriptive method to analyse the data. The study found that restrictiveness in land use regulation varies strongly across municipalities in
Argentina and new development increases and decreases at different locations of the city.

The study of MacDonald and McMillen(2004) employed factor analysis to describe how particular land use regulation tends to have effects on metropolitan area. The study present econometric results in the analysis of the determinants of zoning complexity and used as variable the number of zoning categories for residential, commercial and other uses. The study found out that there are varieties of development regulations for various neighborhood and categories of income level in metropolitan Chicago. The study provided basis for studying zoning as an aspect of land use regulations and the use of inferential statistics for analysis.

Gyourko et al (2008) observed that municipalities within the city centre tend to be more highly regulated than other area. The authors utilized various aspects of land use regulations such as minimum lot size, permit waiting times, growth control to measure the implementation of land use regulation in Wharton. The study provided basis for studying particular aspect of land use regulations and comparing the level of implementation of land use regulations between selected areas. The present study also confined to zoning and building regulation in appraising the implementation of land use regulations for commercial property development across the selected study areas.

Land use regulations are carefully designed; successful implementation is constrained by a lack of technical capacity, limited resources, political tensions, and a lack of understanding of how the land markets actually function (Berrisford, 2013). Duranton, Gobillon, and Overman (2008), studied the effect of changes in government taxation across the local government on behaviour of firms in the study area.

This is a gap in the overall body of literature. This gap is aggravated by the relative absence of a comparative analysis that examines how similar (or even identical) legal tools and instruments have impacted on different country and city contexts. Two exceptions to this are Goodfellow's comparison of the impacts of planning law in Rwanda and Uganda (Goodfellow, 2014a) and McAuslan's examination of the impacts of similar urban planning laws in the countries of East Africa (McAuslan, 2013).

\subsection{Empirical Studies on the Implementation of Land Use Regulations on Commercial Property Development \\ Existing literatures such as Sridhar (2010), examined} the impact of land use regulations in India in terms of strong implementation of land use regulations using econometric techniques. The study found that population suburbanises in response to a relaxation of floor area ratio norms in the suburbs.

Boama, Nelson and Gyimah (2012), examined the implementation of land use regulations and its impact on land value in Ghana. The author reviewed literatures and collated 


\section{International Journal of Engineering Applied Sciences and Technology, 2021 \\ Vol. 6, Issue 5, ISSN No. 2455-2143, Pages 88-99 \\ Published Online September 2021 in IJEAST (http://www.ijeast.com)}

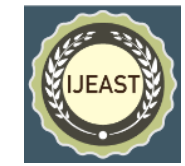

empirical data from land developers so as to find out whether developers are complying with the system of land use regulations in the municipality and to also document the level of implementation of these regulations. The study found that development controls are largely not enforced in $\mathrm{Wa}$ municipality, as a result of building codes not consistent with the socio-economic state of the municipality's residents and led to haphazard development and reduction in land value.

The study of MacDonald and McMillen (2004) employed factor analysis to describe how particular land use regulation tends to have effects on metropolitan area. The study present econometric results in the analysis of the determinants of zoning complexity and used as variable the number of zoning categories for residential, commercial and other uses. The study found out that there are varieties of development regulations for various neighborhood and categories of income level in metropolitan Chicago.

Land use regulations are carefully designed; successful implementation is constrained by a lack of technical capacity, limited resources, political tensions, and a lack of understanding of how the land markets actually function (Berrisford, 2013). Duranton, Gobillon, and Overman (2008), studied the effect of changes in government taxation across the local government on behaviour of firms in the study area.

\subsection{Empirical adaptation from previous Studies on the Implementation of Land Use Regulations on Property Development.}

Previous researcher(s) used (spatial) econometrics to analyze the respondents' opinion, survey of respondents and regulators, ordinary least square regression and testing of hypothesis on impact of land use regulations on landed properties in the selected locations, among others.

Equally, previous studies adopted case study approach, use of questionnaire, interview to collect data from the respondents and used descriptive method to analyse data on the implementation of land use regulations on property development.

This study explored the implementation of land use regulations with special focus on zoning and building regulations on commercial property development in Ilorin, Kwara state, Nigeria. Nonetheless, the available studies have not dealt with implementation of land use regulation on commercial property development especially in the case study. This current study was on implementation of land use regulations on commercial property development; adoption of descriptive method, survey of landlord/tenants of selected commercial properties, regulators (Officials of Kwara State Physical Planning Authority) and Estate Surveyors and Valuers'firm to analyze the data was considered appropriate. The study focuses on the implementation of land use regulations (zoning and building regulations) on commercial property development in Amilegbe - Gambari - Ipata - Emirs road- ita ajia and C.B.N road - Offa road - flower garden, G.R.A Ilorin Kwara state.

Equally, the use of inferential statistics of Mann - Whitney $\mathrm{U}$ Test, Independent Sample $\mathrm{t}$ - Test and test of hypothesis to appraise the implementation of land use regulations on commercial property development in the study area helps to achieve the aim of the study.

\section{MATERIAL AND METHODS}

The research focused on appraisal of the implementation of land use regulations on commercial property development. Survey research design was employed in the research work. To achieve this, two commercial nerve centers with many identified urban issues like traffic gridlock among other problems was selected through deliberate sampling method. Survey design was used because the study sought to appraise the implementation of land use regulations on commercial property development; hence, qualitative survey approach using structured questionnaire was deemed appropriate. This was validated by conducting semi structured interviews (qualitative method) shortly after the questionnaire survey to make the results obtained reliable

A reconnaissance survey was carried out to identify the number of existing commercial properties and sampling frame of the target audience. From pre-survey physical enumeration, a total of 110 commercial properties were identified at Gambari-Ipata-Emir's road from Amilegbe junction to Ita-ajia area, Ilorin, Kwara State. Equally, a total of 39 commercial properties was identified at Government Reserved Area (G.R.A) from Central Bank of Nigeria (CBN) office to flower-garden junction,Offa road, Ilorin, Kwara State, Nigeria.

There are twenty-six (26) Estate Surveying and Valuation firms in Ilorin Kwara State, Nigeria as contained in the 2019 register of the practicing firms in the state.

Since the population of the firms is not numerous, therefore, sample size of twenty-six (26) Estate Surveying and Valuation firms in the study area was used. A census method was adopted for the commercial properties since the identified commercial properties are less than two hundred (200) and is within a manageable size. Questionnaire was administered on landlords/occupants across the selected commercial properties. Similarly, census method was adopted for Estate Surveying and Valuation firms in Ilorin kwara state. Well - structured questionnaire and interview were employed for the research.

For the full survey, questionnaires were administered on landlords/occupants of commercial properties and principal/managing partner of Estate Surveying and Valuation firms in Ilorin Kwara State Cronbach Alpha test was used to test the reliability of the instrument. Data for the study were collected through the administration of structured questionnaires on 110 and 39 selected landlords / occupiers of commercial properties in Gambari-Ipata-Emir's road from Amilegbe junction to Ita-ajia area and Government Reserved Area (G.R.A) Ilorin respectively; and twenty-six (26) 


\section{International Journal of Engineering Applied Sciences and Technology, 2021 \\ Vol. 6, Issue 5, ISSN No. 2455-2143, Pages 88-99 \\ Published Online September 2021 in IJEAST (http://www.ijeast.com)}

principal/managing partner of Estate Surveying and Valuation firms in Ilorin. Data collected were analysed using descriptive statistics of cross tabulation and inferential statistics of Independent Sample $\mathrm{t}-$ Test and test of hypothesis.

\section{RESULTS AND DISCUSSION}

This section presents the analysis of data collected from questionnaires and the discussions of findings that emanates therefrom.

\subsection{Demographic Information of Respondents}

The demographic information of the respondents helps to determine the suitability of the respondents in providing useful response relating to the study. Thus, the succeeding table provides details.

Table 1: Demographic Information of Landlords/Occupants across the Study Areas

\begin{tabular}{|c|c|c|c|c|}
\hline & & \multicolumn{3}{|c|}{ Location } \\
\hline & & Gambari & GRA & Total \\
\hline & Yes & 81 & 23 & 104 \\
\hline Permanent & No & 29 & 13 & 42 \\
\hline Resident & Total & 110 & 36 & 146 \\
\hline \multirow{3}{*}{ Gender } & Male & 61 & 18 & 79 \\
\hline & Female & 49 & 18 & 67 \\
\hline & Total & 110 & 36 & 146 \\
\hline \multirow{5}{*}{$\begin{array}{l}\text { Marital } \\
\text { Status }\end{array}$} & Married & 52 & 18 & 70 \\
\hline & Single & 51 & 13 & 64 \\
\hline & Divorce & 2 & 4 & 6 \\
\hline & Widow & 5 & 1 & 6 \\
\hline & Total & 110 & 36 & 146 \\
\hline \multirow{6}{*}{$\begin{array}{l}\text { Age of } \\
\text { Respondents }\end{array}$} & Belo 30 & 45 & 10 & 55 \\
\hline & $31-40$ & 25 & 13 & 38 \\
\hline & $41-50$ & 16 & 4 & 20 \\
\hline & $51-60$ & 12 & 6 & 18 \\
\hline & 61 years $\&$ above & 12 & 3 & 15 \\
\hline & Total & 110 & 36 & 146 \\
\hline \multirow{7}{*}{$\begin{array}{l}\text { Level of } \\
\text { Education }\end{array}$} & $\begin{array}{l}1^{\text {st }} \text { Sch. Leaving } \\
\text { cert. }\end{array}$ & 17 & 2 & 19 \\
\hline & WAEC/GCE/NECO & 23 & 6 & 29 \\
\hline & NCE & 24 & 18 & 42 \\
\hline & $\mathrm{HND} / \mathrm{BSc}$ & 40 & 9 & 49 \\
\hline & $\mathrm{MSc}$ & 6 & 1 & 7 \\
\hline & Total & 110 & 36 & 146 \\
\hline & Trading & 39 & 7 & 46 \\
\hline
\end{tabular}

\begin{tabular}{llll|} 
Self Employed & 42 & 17 & $\mathbf{5 9}$ \\
Private Company & 13 & 8 & $\mathbf{2 1}$ \\
Retired Personnel & 9 & 1 & $\mathbf{1 0}$ \\
Civil Servant & 7 & 3 & $\mathbf{1 0}$ \\
Total & $\mathbf{1 1 0}$ & $\mathbf{3 6}$ & $\mathbf{1 4 6}$ \\
\hline
\end{tabular}

Source : Field Survey, 2021

Table 1 shows the demographic information of the respondents in the study areas that are landlords/occupiers of commercial properties. The study made use of two locations namely Gambari - Emir's road and G.R.A. There are 146 respondents in all that are landlords/ occupiers of commercial properties. 110 are from Gambari - Emir's road because this area is densely populated and there are 36 respondents from GRA because the area is sparsely populated. Among the 110 respondents from Gambari - Emir's road, 81 are permanent residents of while 29 were not. In the same vein, 23 out of the 36 respondents in GRA are permanent residents while the remaining 13 were not. 61 and 18 of the respondents are male while 49 and 18 were female in Gambari - Emir's road and GRA respectively.

In Gambari - Emir's road, 45 respondents were below 30 years of age, 25 respondents are within the age of 31-40 years 16 respondents are within the age of 41-50 years while 12 respondents are within the age range of 51-60 years. In GRA area, 10 respondents are below 30 years of age, 4 respondents are within the age of 31-40 years, 6 respondents are within the age of 41-50 years while 3 respondents were within the age range of 51-60 years. The age distributions revealed that majority of respondents are of age on commercial activities and therefore their opinion on the study can be relied upon for this study.

The educational qualification of the respondents revealed that, in Gambari - Emir's road, 17 of the respondents are First School Leaving certificate holders, 23 are WAEC/GCE/NECO holders, 24 are NCE holders, 40 are HND/BSc holders and 1 is MSc holder. In GRA area, 2 of the respondents are First School Leaving certificate holders, 6 are WAEC/GCE/NECO holders, 18 are NCE holders, 9 are HND/BSc holders and 1 is MSc holder. This shows that the respondents were educated to give opinion on the impact of land use regulations on commercial property development in Ilorin.

Lastly, the occupation distribution showed that 39 respondents were traders in Gambari - ipata - Emir's road and 7 respondents are traders in G.R.A., 42 respondents are selfemployed in Gambari - ipata - Emir's road and 17 were selfemployed in G.R.A. In Gambari - ipata - Emir's road 13 respondents works in private company and 18 works in private company in GRA, while 9 respondents were retired personnel in Gambari - ipata - Emir's road and 1 respondent was a retired personnel in G.R.A. Equally, 7 respondents were civil servants in Gambari - ipata - Emir's road and 3 


\section{International Journal of Engineering Applied Sciences and Technology, 2021 \\ Vol. 6, Issue 5, ISSN No. 2455-2143, Pages 88-99 \\ Published Online September 2021 in IJEAST (http://www.ijeast.com)}

respondents were civil servants in G.R.A. This shows that large numbers of respondents engages in private activities and provides essential services to the public which therefore stimulates more commercial in the study area, thus information regarding .impact of land use regulations on commercial property development can be retrieved and relied on.

Table 2: Demographic Information of Estate Surveyors and Valuers

\begin{tabular}{|c|c|c|c|}
\hline & & Frequency & Percent \\
\hline \multirow{6}{*}{$\begin{array}{l}\text { Year in } \\
\text { Practice }\end{array}$} & $0-5$ Years & 5 & 20.8 \\
\hline & 6-10 Years & 7 & 29.2 \\
\hline & 11-15 Years & 5 & 20.8 \\
\hline & 16-20 Years & 2 & 8.3 \\
\hline & 21 Years \& above & 5 & 20.8 \\
\hline & Total & 24 & 100.0 \\
\hline \multirow{3}{*}{ Gender } & Male & 23 & 95.8 \\
\hline & Female & 1 & 4.2 \\
\hline & Total & 24 & 100.0 \\
\hline \multirow{6}{*}{$\begin{array}{l}\text { Experience in } \\
\text { land use } \\
\text { regulations }\end{array}$} & $0-5$ Years & 6 & 25.0 \\
\hline & 6-10 Years & 7 & 29.2 \\
\hline & 11-15 Years & 3 & 12.5 \\
\hline & 16-20 Years & 2 & 8.3 \\
\hline & 21 Years and above & 6 & 25.0 \\
\hline & Total & 24 & 100.0 \\
\hline \multirow{4}{*}{$\begin{array}{l}\text { Professional } \\
\text { Qualifications }\end{array}$} & Probational/Graduate & - & - \\
\hline & ANIVS & 20 & 83.3 \\
\hline & FNIVS & 4 & 16.7 \\
\hline & Total & 24 & 100.0 \\
\hline \multirow{7}{*}{ Qualifications } & $\begin{array}{l}\text { National Diploma } \\
\text { (ND) }\end{array}$ & - & - \\
\hline & $\begin{array}{l}\text { Higher National } \\
\text { Diploma (HND) }\end{array}$ & 11 & 45.8 \\
\hline & $\begin{array}{l}\text { Post Graduate } \\
\text { Diploma (PGD) }\end{array}$ & 4 & 16.7 \\
\hline & First Degree & 6 & 25.0 \\
\hline & Master Degree & 2 & 8.3 \\
\hline & Doctorate Degree & 1 & 4.2 \\
\hline & Others & - & - \\
\hline
\end{tabular}

\section{Source: Field survey, 2021}

Table 2 shows that more than $50 \%$ of the Estate Surveying and Valuation firms have been in practice for more than 10 years in the study area. Equally, about $46 \%$ of the Estate Surveying and Valuation firms have more than 10 years experiences in land use regulations in relation to commercial property development in the study area. This implies that the firms have involved in commercial property development/ management and familiar with the subject under consideration. Information provided by the firms can be trusted for the study.

\subsection{Level of Implementation of Land Use Regulations on Commercial Property Development in the Study area}

The information regarding the level of implementation of land use regulations for commercial property development was obtained from the respondents in the study areas. Independent sample $\mathrm{t}$ - test was used to analyse the variation in the level of implementation of land use regulations on commercial property development across the study area.

Table 3: The Level of Implementation of Land Use Regulations on Commercial Property Development in the Study area (See Appendix)

Table 3 shows the result of independent sample t-test to test if there is variation in the level of implementation of land use regulations for commercial property development across the study areas. There are two locations considered in this study hence the choice of $t$-test. The test shows that the $p$-values for all the level of implementation of land use regulations for commercial property development does not vary in the study areas of Ilorin and were greater than 0.01 which led to the acceptance of the null hypothesis that the level of implementation of land use regulations for commercial property development does not vary in the study areas of Ilorin.

It must be noted that, this does not imply that there is no difference in the level of implementation of land use regulations for commercial property development in Gambari - ipata - Emir's road and G.R.A but the difference is not significant. In other words, the implementation level of land use regulations for commercial property development between the two areas was not statistically significant. In order to understand this better, the research explores group statistics as indicated in the table 5 .

Table 4: Group Statistics of Level of Implementation of Land Use Regulations for Commercial Property Development in the study areas

\begin{tabular}{|l|l|l|l|l|l|}
\hline \multicolumn{6}{|c|}{ Group Statistics } \\
\hline & Location & $\mathrm{N}$ & Mean & $\begin{array}{l}\text { Std. } \\
\text { Deviation }\end{array}$ & $\begin{array}{l}\text { Std. } \\
\text { Error } \\
\text { Mean }\end{array}$ \\
\hline
\end{tabular}




\section{International Journal of Engineering Applied Sciences and Technology, 2021 \\ Vol. 6, Issue 5, ISSN No. 2455-2143, Pages 88-99 \\ Published Online September 2021 in IJEAST (http://www.ijeast.com)}

\begin{tabular}{|l|l|l|l|l|l|}
\hline \multirow{2}{*}{ Zoning } & Gambari & 110 & 2.7364 & 1.67374 & 0.15959 \\
\cline { 2 - 6 } & GRA & 36 & 4.3611 & 0.89929 & 0.14988 \\
\hline \multirow{2}{*}{$\begin{array}{l}\text { General } \\
\text { set back }\end{array}$} & Gambari & 110 & 2.3273 & 1.51512 & 0.14446 \\
\cline { 2 - 6 } & GRA & 36 & 3.6389 & 1.22247 & 0.20375 \\
\hline \multirow{2}{*}{$\begin{array}{l}\text { Height } \\
\text { restriction }\end{array}$} & Gambari & 110 & 2.2273 & 1.34546 & 0.12828 \\
\cline { 2 - 6 } & GRA & 36 & 3.6944 & 1.32707 & 0.22118 \\
\hline $\begin{array}{l}\text { Density } \\
\text { control }\end{array}$ & Gambari & 110 & 2.2727 & 1.4201 & 0.1354 \\
\cline { 2 - 6 } & GRA & 36 & 3.5 & 1.4442 & 0.2407 \\
\hline $\begin{array}{l}\text { Plot } \\
\text { coverage }\end{array}$ & Gambari & 110 & 3.2364 & 1.10816 & 0.10566 \\
\cline { 2 - 6 } & GRA & 36 & 3.6389 & 1.29069 & 0.21511 \\
\hline $\begin{array}{l}\text { Provision } \\
\text { of } \\
\text { walkway }\end{array}$ & Gambari & 110 & 2.9909 & 1.22284 & 0.11659 \\
\cline { 2 - 6 } & GRA & 36 & 3.5833 & 1.42177 & 0.23696 \\
\hline
\end{tabular}

Source : Field Survey, 2021

Table 4 shows the mean standard deviation and standard error of the two locations on level of implementation of land use regulations on commercial property development in Ilorin. Zoning is highly recorded at G.R.A (4.36) but averagely effective at Gambari - ipata -Emir's road (2.73), general set back is effective at G.R.A (3.63) but less effective at Gambari - ipata - Emir's road (2.32). Height restriction is effective at G.R.A (3.69) but less effective at Gambari - ipata Emir's road (2.22).

Density control is effective at both G.R.A (3.50) but less effective at Gambari - ipata - Emir's road (2.27). Plot coverage is effective at both G.R.A (3.63) and Gambari - ipata - Emir's road (3.23) and provision of walk way is also effective at G.R.A (3.58) but not effective at Gambari - ipata Emir's road (2.99). Standard deviation of zoning, general set back and height restriction in Gambari - ipata - Emir's road area were higher than that of G.R.A indicating that the average response of landlord/ occupiers of commercial properties in Gambari - ipata - Emir's road area were widely dispersed from one respondent to the other on the implementation of these land use regulation. Equally, standard deviation of density control, plot coverage and provision of walkway in G.R.A were higher than that of Gambari - ipata - Emir's road area. This indicates that the average response of landlord/ occupiers of commercial properties in G.R.A were widely dispersed from one respondent to the other on the implementation of these land use regulations.

The results led to the acceptance of the null hypothesis which equally confirmed that the land use regulations for commercial property development were not strictly implemented across the study area. This is because there were no significant differences in the level of implementation of land use regulations across the study area, however it was not effectively implemented in Gambari - ipata - Emir's road of Ilorin.

The findings of this study are in agreement with the study of Boama, Nelson and Gyimah (2012) on the implementation of land use regulations in Wa municipality, Ghana that development controls are largely not enforced.

\section{CONCLUSION AND RECOMMENDATIONS 5.1 SUMMARY AND CONCLUSION}

The study appraised the implementation of land use regulation on commercial property development in Ilorin kwara state Nigeria. The research presented the mean standard deviation and standard error of the two locations (Gambari-Emir's road and G.R.A) on level of implementation of land use regulations on commercial property development in Ilorin. The test shows that the p-values were all greater than 0.01 indicating that the level of implementation of land use regulations for commercial property development does not vary in the study areas of Ilorin. This implies that, the implementation level of land use regulations on commercial property development between the two areas was not statistically significant. There were no significant differences in the level of implementation of land use regulations across the study area, however it was not effectively implemented in Gambari - Emir's road of Ilorin.

The findings of this study contradict the findings of Brueckner (2017), who examined the stringency of land use regulation in Beijing China. The study found that there was variation in implementation of land use regulation across Chinese cities as a result of site characteristics. Goytia and Pasquini (2013), carried out a study in Argentina and noted that there was variation in the implementation of land use regulations as a result of growth pattern of the city size. Gyourko et al (2008) carried out a study in America and established that implementation of land use regulations varies across metropolitan areas of Wharton, Carlifonia, North - East and Western regions and the stringency of regulations. The variation was as a result of markets and that coastal markets are more regulated compare to North - East region of America and West region of Carlifonia.

Interviews conducted with the heads of the units at the Kwara State Physical Planning Authority (PPA), and Estate Surveyors and Valuers in Ilorin revealed that there are inadequate resources for effective monitoring and enforcement of land use regulations, political interference on approval for application of building/commercial property development in Ilorin.

Conclusively, the study appraised the implementation of land use regulations on commercial property development in Ilorin Kwara State. Census method was adopted to select the appropriate respondents. The finding of this study confirms that the level of implementation of land use regulations on commercial property development does not vary significantly in the study areas of Ilorin, Nigeria 


\section{International Journal of Engineering Applied Sciences and Technology, 2021 \\ Vol. 6, Issue 5, ISSN No. 2455-2143, Pages 88-99 \\ Published Online September 2021 in IJEAST (http://www.ijeast.com)}

This research also shows that implementation level of land use regulations on commercial property development was not impressive and the ease of commercial activities was largely hampered especially in the study area.

It is imperative to state the implication at this point that, there were hindrances to the effective implementations of land use regulation on commercial property development across the study areas, and if not corrected will continue to affect the welfare of the citizens, ease of commercial activities, will lead to falling in commercial property's rental value, falling in urban aesthetic value, and an increase in externalities. These are challenges to the government agencies in land matters and land policy, built up professionals, property developers, land owners, investors to improve the welfare of the populace and ease of commercial activities.

The study of land use regulations (zoning and building regulations) in the field of estate management and valuation has appraised the implementation of land use regulations on commercial property development in such a way to enhance the supply of sustainable commercial properties to the market.

\subsection{RECOMMENDATIONS}

Based on the findings of the study, the following recommendations are put forward: the study recommends proper government intervention in providing better facilities to improve the Physical Planning Authority (PPA)'s technical capacity, adequate resources so as to improve the level of monitoring and enforcement of land use regulations on commercial property development. The master plan of Ilorin should be reviewed and implementation process must continue. In other words, government should provide new standard master plan and be effectively implemented without interference.

\section{CONSENT}

As per international standard or university standard, participant's written consent has been collected and preserved by the authors.

\section{ACKNOWLEDGEMENTS}

The authors acknowledge the support of Nigerian Tertiary Education Trust Fund (Tetfund) through its Academic Staff Training and Development (AST\&D) sponsorship that made the study possible. The authors equally thank lecturers and panel of examiners in the Department of Estate Management, Federal University of Technology Akure, Nigeria during Master of Technology (M.Tech) proposal defence and post survey seminar for their comments and suggestions.

\section{COMPETING INTERESTS}

Authors have declared that no competing interests exist.

\section{REFERENCE}

[1] Abiodun, A.O., Olaitan, O. O., \& Abimbola, T. A. (2018). Planning regulations and implementation mechanisms in postcolonial Lagos. Journal of Globalization Studies, 9(1).

[2] Retrieved on $23^{\text {rd }}$ July, 2021 From: http://www.researchgate.net.

[3] Berrisford, S. (2013). Getting land governance right in sub-saharan African cities: more than land administration. Trading Places: Accessing land in African Cities. Pp. 7390.

[4] Boama, N.A, Nelson, J. K. B \& Gyimah, C. (2012), The impact of land use regulations on residential land values in the Wa Municipality, Ghana. Springer Science Business media. Journal of Housing and the built environment, 27: Pp.349-358

[5] Braissoulis, H.(1999), Sustainable development and the informal sector: an uneasy relationship. Journal of Environmental Devlopment. 8(3): Pp.213-237

[6] Bramley,G. (2013), Housing market models and planning. Town Planning Review 84: Pp. 9-35

[7] Brueckner, J. K., Fu, S., Gu, Y., \& Zhang, J. (2017). Measuring the stringency of land use regulation: The case of China's building height limits. Review of Economics and Statistics, 99(4), 663-677. Retrieved on $23^{\text {rd }}$ July, 2021

From:

http://www.mitpressjournals.org/doi/pdf/10.1162/REST

[8] Cheshire, P.C \& Hilber, C.A.L( 2008), Office space supply restrictions in Britain: The Political economy of market revenge, Economic Journal, 118 (529): F185F221

[9] Cheshire, P.C., Hilber,CAL and Kaplanis, I (2015), Land use regulation and productivity-land matters; evidence from Uk Supermarket Chain. Journal of Economic Geography 15: Pp.43-73.

[10] Duranton, G., Gobillon, L., and Overman, H.G.(2008), Assessing the effects of local taxation using Microgeographic Data. Processed, University of Toronto.

[11] Evans, A. (2004), Economics and land use planning. Blackwell Publishing. Oxford. Retrieved Retrieved on June, $16^{\text {th }}, 2019$, from: https://doi.org.

[12] Fischel, W.A. (2004), Aneconomic history of zoning and acure for its exclusionary effects. Urban Studies, 41(2): Pp.317-340.

[13] Glaeser, E.L \& Ward, B. A. (2009), The causes and consequences of land use regulations: evidence from greater Boston. Journal of Urban Economics 65(3); Pp.265-278

[14] Glaeser, E.L., Gyourko,J, \& Saks, R.E.(2005), Why is Manhatttan so expensive? regulation and the rise in house 


\section{International Journal of Engineering Applied Sciences and Technology, 2021 \\ Vol. 6, Issue 5, ISSN No. 2455-2143, Pages 88-99 \\ Published Online September 2021 in IJEAST (http://www.ijeast.com)}

prices, Journal of Law and Economics, 48(2); Pp.331369.

[15] Glaeser, E. L. (2017). Reforming land use regulations. Brookings Center on Regulation and Markets. Accessed August, 22, 2019.

[16] Goçmen, Z. A. (2013). Barriers to successful implementation of conservation subdivision design: A closer look at land use regulations and subdivision permitting process. Landscape and Urban Planning, 110, 123-133. Retrieved on 23 ${ }^{\text {rd }}$ July, 2021 From: http://www.semanticscholar.org/paper/Barriers-tosuccessful-implementation-of-design

[17] Goodfellow, T. (2014a). Planning and development regulation amid rapid urban growth: Explaining divergent trajectories in Africa. Geoforum, 48, Pp. 8393.

[18] Gyourko, J. Saiz, A., Summers, A. (2008), A new measure of the local regulatory environment for housing markets: The Wharton residential land use regulatory index. Urban Studies, 45(3): Pp.693-729.

[19] Goyita, C. \& Pasquini, R. (2010), Land regulation in the urban agglomerates of argentina and its relationship with households' residential tenure condition. Lincoln Institute of Land Policy, Cambridge, M.A. Pp.27-30

[20] Goytia and Pasquini (2013), Assessing urban land use regulation in argentina: Literature review and research strategy. Lincoln Institute of Land Policy

[21] Guy, S \& Henneberry, J. (2000), Understanding urban development process; integrating the economic and social in property research. Urban Studies 37 (13), Pp.23992416.

[22] Hanushek, E.A. Qugley, J.M. (2012), Commercial land use, land use regulation and local government finance. American economic association. The American economic Review, 80(2).

[23] Heller, M.(1998), The tragedy of the anti-commons: property in the transition from Marx to Markets, 111 HARV.L REV.621

[24] Hilber, C.A.L. \& Robert-Nicaoud (2010), On the origins of land use regulations: theory and evidence from US metro areas. London school of economic. Retrieved on June, $23^{\text {rd }}$, 2019, from: https://doi.org.

[25] Hilber, C. A., \& Robert-Nicoud, F. (2013). On the origins of land use regulations: Theory and evidence from US metro areas. Journal of Urban Economics, 75, Pp.29-43.

[26] Jaeger, W. K.(2006), The effects of land use regulations on property values, oregon state University, Corvallis, Oregon. 36 (1); Pp.105-127

[27] Ling, D. C. \& Archer, W.R.(2013), Real estate principles; avalue approach. New York. The McGraw-Hill Companies.
[28] MacDonald \& McMillen(2004), Determinants of suburban development controls; a fischel expedition. Urban Studies, 41(2); Pp.341-361

[29] McAuslan, P. (2013). Land Law Reform in Eastern Africa: Traditional or Transformative?: A critical review of 50 years of land law reform in Eastern Africa 19612011. Routledge.

[30] NPC (1991), Provisional Census Figure:, Lagos

[31] NPC (2006), Provisional Census Figure:, Abuja

[32] Odeniyi, P. (2007), "Census 2006: North is $75 \mathrm{~m}$, South $64 \mathrm{~m}$ " in the nation newspaper, volume1, No 0164, January 10.

[33] Oduwaiye, L, Alade, W. \& Adekunle, S. (2011), Land use traffic pattern along Lagos-Badagrycorridor, Lagos , Nigeria. Proceedings REAL CORP 2011 Tagungsband 18-20 May, Pp.525-532. Retrieved from: http:www.corp.at.

[34] Oyesiku, K.(1998), Modern urban and regional planning law and administration in Nigeria. Printmarks Ventures, Osasanmi, Ibadan.

[35] Power, A. (2004), Sustainable communities and sustainable development: A review of the sustainable communities plan. Case report 23. London school of economics.Centre analysis of social exclusion. Retrieved from https://scholar.google.com

[36] Quigley, J.(2007), Regulation and property values in the United States: The high cost of monopoly, in G.Ingram andY.H.Hong (Eds) Land policies and their outcomes, (Pp.46-66). Cambridge, M.A: Lincoln Institute of Land Policy.

[37] Robert-Nicoud, F. \& Hilber, C. (2013), On the causes and consequences of land use regulations. VOX CEPR Policy Portal Retreived from:https://doi.org.

[38] Spark, J. L. (2009), Land use regulation in arizona after the private property rights protection act. University of Arizona James E.Rogers College of Law. Retreived on $23^{\text {rd }}$ June, 2019 from:https://www.scholar.google.com

[39] Sridhar, K. S. (2010). Impact of land use regulations: Evidence from India's cities. Urban Studies, 47(7), Pp.1541-1569

[40] Turner, M.A.,Haughwout, A. \&Van der Klaauw, W.(2014)",Land use regulation and welfare. Econometrical 82(4); Pp.341-403.

[41] Toivonen, S. \& Viitanen, K.(2016), Environmental scanning and futures wheels as tools to analyze the possible future themes of commercial real estate market. Land use policy, 52(1); (Pp.51-61). Retrieved on the $15^{\text {th }}$ June, 2019 from http://dx.doi.org/10.1016/j.landusepol.

[42] Wang, Z., \& Zhang, Q. (2014), To violate or not? Land use regulations and implementation in urban China. Working Paper, School of Economics, Fudan University. 
International Journal of Engineering Applied Sciences and Technology, 2021

Vol. 6, Issue 5, ISSN No. 2455-2143, Pages 88-99

Published Online September 2021 in IJEAST (http://www.ijeast.com)

Table 3: Independent Sample T- Test on the Level of Implementation of Land Use Regulations for Commercial Property Development in the study areas

Independent Samples Test

\begin{tabular}{|c|c|c|c|c|c|c|c|c|c|c|}
\hline \multicolumn{11}{|c|}{ Independent Samples Test } \\
\hline \multirow[t]{3}{*}{ Land Use Regulations } & & \multicolumn{2}{|c|}{$\begin{array}{l}\text { Levene's Test for } \\
\text { Equality of } \\
\text { Variances }\end{array}$} & \multicolumn{7}{|c|}{ t-test for Equality of Means } \\
\hline & & \multirow[t]{2}{*}{$\mathrm{F}$} & \multirow[t]{2}{*}{ Sig. } & \multirow[t]{2}{*}{$\mathrm{T}$} & \multirow[t]{2}{*}{ Df } & \multirow[t]{2}{*}{$\begin{array}{l}\text { Sig. (2- } \\
\text { tailed) }\end{array}$} & \multirow[t]{2}{*}{$\begin{array}{l}\text { Mean } \\
\text { Difference }\end{array}$} & \multirow[t]{2}{*}{$\begin{array}{l}\text { Std. Error } \\
\text { Difference }\end{array}$} & \multicolumn{2}{|c|}{$\begin{array}{l}\text { 95\% Confidence Interval of } \\
\text { the Difference }\end{array}$} \\
\hline & & & & & & & & & Lower & Upper \\
\hline Zoning & Equal variances not assumed & & & -7.421 & 112.792 & 0 & -1.62475 & 0.21893 & -2.0585 & -1.19099 \\
\hline \multirow[t]{2}{*}{ General set back } & Equal variances assumed & 8.118 & 0.005 & -4.713 & 144 & 0 & -1.31162 & 0.27831 & -1.86171 & -0.76152 \\
\hline & Equal variances not assumed & & & -5.251 & 73.103 & 0 & -1.31162 & 0.24976 & -1.80938 & -0.81385 \\
\hline Height restriction & Equal variances assumed & 0.011 & 0.917 & -5.698 & 144 & 0 & -1.46717 & 0.25749 & -1.97612 & -0.95822 \\
\hline \multirow[t]{2}{*}{ Density control } & Equal variances assumed & 0.32 & 0.573 & -4.482 & 144 & 0 & -1.22727 & 0.27381 & -1.76848 & -0.68607 \\
\hline & Equal variances not assumed & & & -4.444 & 58.766 & 0 & -1.22727 & 0.27617 & -1.77993 & -0.67461 \\
\hline \multirow[t]{2}{*}{ Plot coverage } & Equal variances assumed & 3.611 & 0.059 & -1.815 & 144 & 0.072 & -0.40253 & 0.22181 & -0.84095 & 0.0359 \\
\hline & Equal variances not assumed & & & -1.68 & 52.936 & 0.099 & -0.40253 & 0.23966 & -0.88324 & 0.07819 \\
\hline \multirow[t]{2}{*}{ Provision of walkway } & Equal variances assumed & 4.863 & 0.029 & -2.422 & 144 & 0.017 & -0.59242 & 0.24463 & -1.07596 & -0.10889 \\
\hline & Equal variances not assumed & & & -2.243 & 53.001 & 0.029 & -0.59242 & 0.26409 & -1.12213 & -0.06272 \\
\hline
\end{tabular}

Source : Field Survey, 2021 